\title{
Paul's Resurrection in I Corinthians 15:33-54 in Contradistinction to Reincarnation in Igbo Cosmology
}

\author{
Valentine Chukwujekwu Mbachi
}

\begin{abstract}
This article examines Paul's concept of resurrection in 1 Corinthians 15:33-54 in contradistinction to reincarnation in Igbo cosmology. The approach has been analytical or qualitative. The historicalcritical method and contextual tools are used in the interpretation of the Bible text. Paul sees resurrection as a miracle, a one-time event that is not repetitive, with a body that is not only in continuity with the original body but also new, transformed and glorious and is not subject to earthly limitations. These stand in sharp contrast to Igbo cosmological notions of reincarnation where the phenomenon is a natural process, repetitive, non-identical with the former body and where the new body is subject to all the earthly limitations. Reincarnation in Igbo cosmology runs contrary to the teachings of the Scriptures. This therefore has theological implications for Christian ministry for the Church in Igboland.
\end{abstract}

\section{Introduction}

The Igbo of Nigeria believe in reincarnation, which, as a religious belief, affects their openness to certain Christian doctrines especially those concerning death and the afterlife. This belief is mixed up with other beliefs like the cult of ancestors, belief in the spirits, and the cult of Chukwu (God). The belief in reincarnation affects Christians at many levels ranging from belief, experience, and ritual relation to their ancestors (Obilor 1994). The levels are intrinsically bound together and cause great harm to the Igbo Christian, especially when conversion to Christianity fails to address experiences in everyday life. Continued adherence to the beliefs and practices of traditional religion that reveals belief in reincarnation has not only weakened the Church but has also given rise to syncretism. For instance, in certain cases of child illness, when medical expertise appears not to proffer a solution, an elder would come in and ask the question: "Has the ancestor who came back in this child been determined?" ("Agbaana nwata nke a agu. '). In many such cases, the parents, on being questioned, would go in search of a dibia-afa (fortuneteller) to find out who came back in the child and subsequently to welcome such an ancestor with appro priate honours. In some cases, the sickness appears to subside after the rituals. Some Christian families unfortunately get involved in this act. It is an open secret that when a case becomes a matter of life and death, Christianity is often put aside and the traditional religion takes over in the life of some Christians who would aptly assent that "Ije-uka adighikwa na nke a" ("Going to Church will not limit ones action in this matter").

There is a phrase commonly used among some Igbo Christians which gives credence to reincarnation, and that phrase is none other than, "N'uwa m ozo" ("in my next world”). For example, "N'uwa m ozo m ga-abu nke a ma-obu nke ozo" ("In my next world, I would be this or that"). A prominent Church leader, was heard to confess in one of his preachings, "N'uwa $m$ ozo mghaghi abukwa onye isi Ojii" ("In my next world, I would not be an African"). That is the crux of the matter. If some Church leaders are doing or saying things suggestive of reincarnation, do we then expect the congregations to do less? This, of course, is contrary to the biblical teaching that it is appointed unto men once to die, and after death comes judgment (Hebrews 9:27; 2 Corinthians 5:10).

This therefore reveals a gap in knowledge among some Igbo Christians who are being converted from traditional religion to Christianity. The Igbo Christian is so fundamentally bound to these indigenous beliefs as to present a stiff resistance to key Christian contentions such as resurrection.

The author is concerned that the problem of reincarnation has become such a hot topic and has assumed such different forms in the present times that it can no longer be treated as an ancient belief of "pagan peoples”. Ezeaku (personal communication, August 8, 
2019) saw it as a "challenge to Christianity". Kasper, (cited by Obilor 1994) spoke about the dangers to faith of the theories of reincarnation. According to him, it is necessary to respond to "this syncretistic vision of the world and of life" (111). This article therefore will show that, in the light of 1 Corinthians 15:33-54, the Igbo belief in reincarnation stands in marked contrast to bodily resurrection. The article is qualitative or analytical in approach. The historical-critical method and other contextual tools were used in the interpretation of the biblical text.

\section{Exegetical Analysis and Discussion of 1 Corinthians 15:33-54}

In 1 Corinthians 15:1-34, Paul discusses Christ's resurrection; the resurrection of Christ as the basis of believers' resurrection; the resurrection of Jesus and its universal implications; and, pointing to baptism on behalf of the dead, Christian suffering and the beast of Ephesus as evidence from Christian experience. In 1 Corinthians 15:33-54, he turns his attention to the nature of the resurrection body. The underlying theme in 1 Corinthians 15 is that the bodies of the faithful will be raised, transformed and be made like that of the Lord's resurrection body. The nature of the Lord's resurrection body therefore forms the backbone of Paul's discussion on the nature of the resurrection of the believers. Pannenberg (1968) expresses the view that Paul must have had the mental image of the resurrection of Jesus in this passage because he describes the resurrection of Jesus and that of Christians as two completely parallel events.

No doubt Christians have long been battling over the issue of the nature of the resurrection body. How possible will it be for the dead to rise? Are they likely to rise up from the grave with skeletons and corruption and with all their associated bodily weaknesses? If so, of what value will the resurrection be? It is doubtful if the Corinthians were doubting the possibility of miracles because they had never questioned the reanimation of corpses by God. But this is not to deny the fact that they were wondering why corpses which have fallen into decay should be animated.

We have no way of knowing whether Paul posed his own question in verse 35 or whether he was dealing with a question raised at Corinth. But one thing is clear; either Paul quotes someone or uses the words he imagined any objector would use. One major problem is the correct rendering of the question: Posegeirontai hoi nekroi? Most Bible translators and commentators render it: "How are the dead raised?" This translation links it closely with: Poio de somatierchontai? "With what kind of body do they come?" Philips prefers: "How is the resurrection achieved?" Others have it translated: "Is it possible that the dead are raised?"
Abogunrin (1991) argued that alla (but) is the writer's own words and not the objector's and therefore, "How are the dead raised?" is possibly mistranslated. He concluded that the Corinthians were saying that they could not be expected to believe what was impracticable and unimaginable. Nevertheless, "How are the dead raised?" appeared to be a better translation in that it queries the mechanics of the process. "With what kind of body will they come?" inquires as to the form they will have. Morris (1960) underscores that "these Greek sceptics having understood that a body quickly turns into a heap of decomposed rubbish thought to laugh the idea of resurrection out of court with their query about the body"(219).

In verse 36, Paul refers to them as "fools". The objectors must be foolish to suppose that the resurrection body would be exactly like the mortal body or a continuation of life on earth. The impact is really to make it clear that what Paul has been saying is not without parallels in familiar things around them. If they could only reflect on what they were doing for a moment, they would have an answer to the objections from activities they often engaged in. Paul says that it is common knowledge that new plants never appear unless the seeds first decay. In the light of this, to think that what is "dead" cannot be raised is for Wilson (1978) "in flagrant contradiction to the facts of experience” (229). It appears as if their familiarity with the marvel of harvest has dulled their sense of wonder.

For Paul, they sowed seed which was destroyed, at least in the form in which it was sown. The act of sowing (a "burial") was so similar to what follows death among humankind that Paul could refer to the grain as dying (Jn. 12:24). Stressing this metaphor further, he says that the growth that follows is a giving of new life and that new life does not come unless the grain first "dies". The seed must be destroyed if the new life is to appear. The seed which decays is rather quickened. Hence, anytime they sow, they provide answers to their objections. In other words, that human organisms are destroyed at death is not a negation of bodily resurrection. It has to be noted that Paul does not intend to discuss the laws governing the cultivation, germination and growth of plants for he foresees that such a venture would lead to wrong perception and interpretation of the process of resurrection. For Paul, the birth of a plant is nothing other than a miracle from God who not only gives each seed a body but also life. In contradistinction to the doctrine of immortality of soul, Paul sees the doctrine of the resurrection as a miracle.

Paul teaches that during the time of sowing, we sow nothing more than just a seed. Again, we notice that at sowing we observe that there is no indication of the plant with its stem and leaves and flowers. They naturally appear. A closer examination reveals that there is a beautiful combination of both similarities and 
differences. While the difference between seed and plant is obvious, their identity is profound in that the seed produces that particular plant and no other.

In the same vein, it amounts to no resurrection at all if new beings that basically have no connections with the dead persons are raised. It will simply mean that God is creating new beings with no links to old ones. Consequently, Paul presents a catalogue variety of bodies in the human world. Paul teaches that just as God made different bodies of plants, animals and heavenly bodies, surely will $\mathrm{He}$ clothe resurrected people with suitable resurrection bodies.

The concept of "the body" is central in Pauline theology, and no aspect of his theology has generated more controversy than this. The term soma (body) connects most of his important themes. Robinson (1952) has remarked that apart from Paul's doctrine of God, all other tenets of his doctrine are represented in his understanding of the body. He lists them as: the doctrine of man, the doctrine of sin, the incarnation and atonement, the Church, the sacraments, sanctification and eschatology. As a result, one may ask: What is the resurrection body for Paul?

Opinions are divided. Bultmann (1965) has proposed a straight-forward thesis that Paul generally uses the Hebrew concept of body, which connotes, not the body as opposed to soul, not matter as opposed to form, but the whole person. A person does not have a soma; he or she is soma. The context of Bultmann's thesis is the problem associated with "the Corinthian's sceptics" (429) who satirically posed a rhetorical question about the dead: "What sort of the body do they have when they come back?" (1 Cor. 15:35). Brown (1974) has discussed this problem in relation to the resurrection of Christ and concluded that bodily resurrection needs a direct intervention from outside history, an eschatological context with respect to time and space.

The crux of the question is whether Paul, by his use of the analogy of the seed which dies and the new plant which springs up implies that there is no continuity between the seed and the new plant. Sider (1978) has asked whether Paul by stressing the difference between the seed and the new plant implies "as many scholars have suggested, that there is no continuity between the two". Abogunrin (1991) discusses what he calls "four antitheses" (95) to distinguish between the earthly body and the resurrection body: perishable and imperishable; dishonour and glory; weakness and power; and mental and spiritual. Abogunrin maintains that it is the body which demonstrates continuity and that it is on the body that God's initiatives are wrought. For him, this corporeal, somatic continuity is seen as persisting through a deep, radical and definitive transformation of our being: resurrection.
One must note here what Abogunrin calls somatic continuity. Marxen (1968) has said that in 1 Corinthians 15:35ff, Paul's description of the resurrection body as "imperishable" means that he intended it as totaliter aliter from the terrestrial body. This interpretation is wrong if we agree with Abogunrin in his "somatic continuity". Dahl (1978) also says that although the resurrection body will not be materially identical with the one we now posses, it will be what he chooses to call "somatically identical" (10). In this case, Dahl and Abogunrin agree against Marxen. Cravig (1953) believes that since Paul's stress is on "the complete difference between the two", what is important is "the body which God has chosen, not one that develops naturally from the previous one" (244). Jeremias (1955, 56) argues that what is put into the earth is wholly different from what grows up. Then, Hering (1964) is of the opinion that what Paul intends to stress is the divine intervention rather than a natural process of growth. However, Davies (1962) believes that because Paul was a Jew and because the popular Jewish view was exceedingly materialistic, even the more refined spiritual conception was "not inconsistent with the belief in the bodily resurrection" (307).

Be that as it may, soma does not refer to the part of the human body which perishes at death. This aspect is called sarx (flesh). This corresponds to the Hebrew basar (1. Cor. 15:50). Soma appears not to have an equivalent in Hebrew. Soma not only makes all persons into a life bundle but also into the necessary vehicle of human mediations with the external world, with other people, and even with our maker. It renders the human person from sinner to final glorification in God. Of course, the teachings of dualism that see people as body-soul are irreconcilable with Paul's idea of soma. Consequently, Paul could not help but reject the notion that only part of a human being will survive death in 1 Corinthians 15. For Paul, it is the entire person that survives death and it is the entire person that rises again whether one talks of psyche as for the Platonists or spirit as for the Gnostics. According to Paul, our body is at present laden with death (Rom. 7:24); mortal (Rom. 8:10f); perishable (1 Cor. 15:44-46); humiliated and humiliating (Phil. 3:21); and groans (11 Cor. 4:2,4). But then, it is capable of being changed into an imperishable, spiritual, glorious body. When we are raised up by Christ, our bodies will be transformed to be like that of Christ's, whom God raised up gloriously. This act of God will constitute God's triumphant act of conquest in Jesus Christ.

The apostle Paul points out the nature and extent of continuity and discontinuity as we have it in the seed and plant analogy. He affirms that our body which is subject to decay (plethora) is at death sown corruptible only to be raised incorruptible. By the use of the word plethora, Paul means more than mere physical 
disintegration at death. He sees corruption as a powerful evil that affects all creation as a result of Adam's disobedience. Whereas death and corruption are the aftermath of sin, victory over sin, death and corruption will result from resurrection. The body is in all respects no evil but a gift of the Creator from whom all good things do proceed. To distinguish the first Adam and the second Adam (Christ), the second Adam is to help us understand the ideas that are connected to the natural body (psuchikon) as opposed to the spiritual body (pneumatikon). Paul refers to the first Adam as a man of dust (cf. Syr. Apol. 48:42ff). However, in the place of death and corruption which came through the first Adam who was made a living being, the last Adam is made a life-giving Spirit. At present, we bear the image of the "man of dust" which will later be changed to the image of Christ, the "heavenly man" at the resurrection. Given that there is authentic bodily continuity in that it is what is sown perishable that is raised imperishable; what is sown in dishonour that is raised in glory; what is sown in weakness that is raised in power, there is marked discontinuity in that there must be a marked transformation. For Paul, the spiritual body is quite different from the material body.

In verse 49 , instead of predicting what Christians would be like, Paul encourages Christians to bear the image of the "heavenly man" in this life. For the apostle, the process towards the final victory must start here and now. It appears that there are two interpretations of verse 50. One idea is that it refers to those who are still living at the Parousia and who must of necessity be transformed since they still possess bodies subject to death and corruption. Another interpretation connects the verse with those living an immoral life who have not undergone a spiritual rebirth. It is evident that three elements of discontinuity are clear in Paul: sin, death, its consequences and freedom from sin and death; perishability; mortality and immortality.

\section{Igbo Cosmology}

Like every other people, the Igbo have their own unique worldview. According to Metuh (1985) the Igbo know only one world inhabited by both visible and invisible beings. For Anozia (1968), "The Igbo world whether visible or invisible was a 'real' world in every sense of the word" (2). It is in this understanding that Uzukwu (cited in Obilor 1994) regarded the Igbo world as a world, "Where time and space, objects and persons are made sacred ... where from cradle to grave life is moving towards fullness through dynamic interaction between the human community and its spiritual originators" (117).

This sacralized worldview also extends to commerce. Each Igbo day is a market day and is dedicated to a spirit: Eke, Orie, Afọ and Nkwọ. This is repeated in the same order. The Igbo believe in a three-step structured hierarchical order of the hereafter: the land of Chukwu (God), the land of the non-human spirits like Ana or Ala, and that of the human spirits with special reference to the ancestors. Obilor (1994) pointed out that there are three relations which maintain equilibrium in Igbo thought: cosmic, social, and religious. The three relations are viewed both from the spirit world and the world of humans. Both Chukwu and the gods expect a harmonious co-existence among the three. Man is said to be responsible for any disharmony or disequilibrium. Any disorder arising from any of the three relations is attributed to human negligence or transgressions. Thus, natural disaster, epidemics, famine, certain deaths, and all that is considered unnatural are attributed to human 'sin' and 'wrong doings'. These are ultimately traced to the violation of taboos, nso (abomination), aru (evil) like the sin of sorcery, homicide, suicide, incest, false oath, theft, etc. In this worldview, any evil in the world is caused by human beings.

The Igbo thoughts and ideas are usually experimental, concrete, practical and inductive rather than abstract and deductive. For instance, the Igbo relate to God through His self-manifestations and approach the destiny of man through the value and reward of good life. This approach extends to their idea of reincarnation and retribution. Reincarnation is therefore not only the effort to unite the visible and invisible spheres of existence but also to give value and reward to good life by the ancestors.

For the Igbo, justice in its most perfect form exists in God. For them, justice takes its bearing from God and not from humans. Nzomiwu (1999) noted that in the Igbo thought, "All other beings are just according to the degree of their propinquity to God" (77). God is understood as the source of all justice. God has some names which indicate what the Igbo believe about Him. For example, He is Chukwu (Chi-ukwu, the great God), Chineke (Chi-n'eke, the God that creates), Oseburuwa (Lord who upholds the world), Amamikpe nke ndi ikpe (the Judge of the judges), and Nwoke oghorogho anya (One with very wide eyes, thereby implying that He can see all things).

From the point of view of origin and final destiny, mmadu (man) for Igbo belongs to Chukwu. God at the moment of conception creates the spirit of the wouldbe person. Metuh (1985) concisely put it this way: "The spirit that will be born goes before Chukwu to receive his 'Ch' (spirit destiny) and his 'Eke' (reincarnating ancestor), and then the Okike (creative emanation of Chukwu) lets him out into the world" (40). However, I doubt whether Metuh's stance is a true representation of Igbo belief. This is because the Igbo understand God as wholly other. It is this incomprehensibility of the God of Igbo beliefs that lead the Igbo people to call 
Him Ama-ama amasiamasi (One whose activities are known, yet not known). He is Chukwu-Okike or Chineke meaning the creator of all things. He stands outside all human configurations and classifications. To classify Him is to reduce Him to the level of divinities. In Igbo thought, He is therefore not one of the beings the Igbo can classify. He alone enjoys the prerogative of creation and does not need the assistance of the ancestors. While it is believed that original creation is done by God, the subsequent reincarnations are at the mercy of the ancestors. Therefore, to say that God together with the ancestors works to achieve reincarnation is a false claim.

However the two elements which come together to make up what can be called the identity of humanity must immediately be underlined. The 'chi not only determines one's destiny, it brings it to the proper end, and thus the Igbo would say, "ebe onye dara ka chi ya kwaturu ya" ("where a person falls, there his Chi pushed him down"). The 'Eke' on the other hand refers to the person's shape, character or certain qualities. According to Obilor (1994), when these qualities are derived from a similar ancestor, or any good dead person as the case may be, the Igbo say that the child is the 'reincarnation of that ancestor or the person' (p.121). If Obilor is correct, it means that what the Igbo consider as reincarnation is hereditary traits personified. However, Ekwunife (1999) and Obilor (1994) view reincarnation as the process by which certain categories of the deceased in the African spiritual world of the dead are believed to be mysteriously, but in a real way, capable of incarnating their personality traits on the physical body of a newborn child without either destroying the unique personality of the child or substituting for it.

Some people promise while still alive that they will come back after their death and show signs of their identity. They do so to assert their uprightness and firm conviction that they will not only be admitted into the cult of ancestors but also be rewarded with reincarnation. In this case, there is no doubt and people at the birth of a child can identify him or her immediately. When there is doubt, then it is the work of the dibia afa (diviner) to identify the reincarnated person.

The Igbo believe that humans survive after death. Death is a passage into the community of the 'living dead', a separation and not an annihilation, a bridge to another existence, a reality which is awaited with 'anxiety', ina uno (returning home), ila ala mmuo (returning to the land of the spirits) especially ala nnanna anyi (the land of our ancestors). The Igbo believe that the dead are living side-by-side with them. One can say that for the Igbo, the dead are regarded as people who have completed their work. The wicked and the just do not share the same realm after death in Igbo thought. While the just join the ancestors or 'community of the saints', the wicked are believed to pass on to oblivion or stay at the region referred to by Isidienu (2015) as, "As agbata ụwa na-agbatammuọ" (111) ("the boundary between the living and the dead"). There is no general consensus about the abode of the wicked in Igboland.

Mourning for the dead is religiously observed in Igboland. The period of mourning depends on certain factors. If the deceased is a titled person, the period is usually longer. What used to be common practice in Igboland is a one year mourning period. Death affects whatever the deceased owned and renders it unclean. Therefore, purificatory sacrifices are performed. The Igbo have the practice of shaving the head or wearing mourning dress for a period of one year as a sign of respect for the dead.

The most important sphere of the hereafter is the 'ancestral community'-the community of the dead. The ancestors who are in their permanent rest are conceived to be with Chukwu (God) and can help the living because they are closer to the Supreme Being. This does not refer to a condition of being with God as parents are with their children. It rather refers to the community of the ancestors which the Igbo people believe to be God's community. God in relation to creatures is considered to be completely other. The dead are believed to return to Chukwu only to take their rightful place among the ancestors commensurate with the way they conducted their life here on earth. The help which comes from Chukwu is often believed to reach human beings through the intermediaries. The ancestors are believed to be the major intermediaries.

The ancestors admit new members and give them their rightful place. This admittance is believed to be based on a spotless life, ripe old age, founding lineages, and proper burial, as the case may be. These conditions are not within the reach of the poor, the invalids, and those who die young. The living do their best to win the favour of the ancestors and to be in line with the moral discipline of the clan. That is the reason why some of them, being propelled by their own good works, can give vent to their future possible reincarnations when they die, and which sometimes appear to be true in living people. Thus, the living are expected to live a good and holy life to enable them to get a reward of good rest among the ancestors for possible future reincarnations.

For the Igbo the hereafter in the ancestral community is the real home. It is a continuation of this life where the degree of joy is determined by the quality of life lived on the earth. The concept of the hereafter appears to control morality. The belief in reincarnation gives it its visible expression and attempts to make it relevant to practical life. This is because many strive to live up to the moral discipline of the clan so as to be 
rewarded with reincarnation by the ancestors. The ancestors are leaders in this community. They admit new members and give them their rightful place. For Obilor (1994), all decisions about who will return, the shape, the form, and their qualities are taken in the hereafter by the community of the ancestors in strict accord with Chukwu who finally sends the person to the earth through birth. The phrase "in strict accord with Chukwu" by Obilor is rather unclear. However, the Igbo believe that God can only reach them through intermediaries. One of those intermediaries is the ancestors. They believe that the ancestors are mediating between God and the living. In that sense they can be viewed as discharging their functions in complete harmony with God. God is beyond their reach, but the ancestors are believed to be the leaders in the family of the living-dead. They are not only concerned with this community, they are equally the invisible police of families and communities'.

\section{Reincarnation in Igbo Worldview}

The Igbo concept of reincarnation is a complex one and is viewed in various ways. While some people such as Obilor (1994) and Ekwunife (1999) are of the opinion that we should be using the term ilo-uwa instead of reincarnation ${ }^{1}$, others refer to "partial reincarnation”. For instance, Mbachi (2019) noted that while some describe cyclical reincarnation with a maximum number of three to seven opportunities to be reborn, others hold to a cyclical form of reincarnation as an unending process. I therefore hold the opinion that the matter of how many times an ancestor can reincarnate is an open question in Igbo thought.

According to Onyewuenyi (1989), Obilor (1994), and Ekwunife (1999), for the Igbo, reincarnation is a phenomenon in which an identifiable personality in the Igbo spiritual world is believed in a mysterious but real way to transmit his or her personality traits on a newborn personality without destroying that personality or substituting himself or herself for that new personality. In doing so, the said reincarnate person still retains his or her complete personal identity in the Igbo spiritual world of the dead. By virtue of the power the person commands as a spirit, he or she is able to impress former traits on the newborn child.
However, I doubt whether the concept of reincarnation as shared by the above scholars is the true representation of the Igbo concept of reincarnation. In the spiritual anatomy of humanity in Igbo cosmology, mmadu (man) is neither a dichotomy of body and soul nor a trichotomy of body, soul, and spirit. Mmadu is a unity of personality. The Igboman, for instance, believes that Okeke noro uwa (Okeke reincarnated) and not an aspect or part of Okeke or his "mystical influence" (Ekwunife 1999, 21), or "life-giving will or vital influence or secretion of vital force" (Onyewuenyi $1989,39)$, as the above scholars suggest. I therefore disagree with them in that one cannot reconcile the "mystical influence," "life-giving will" or "vital influence" or "secretion of vital force" with the Igbo concept of human personality. Besides, the Igbo often speak of "ndi mmadu" (humans) and "ndi mmuo" (spirits). Hence "spirits" and "humans" are both persons, as indicated by the prefix, "ndi". The terms, "mystical influence," "life-giving will," "vital influence," or "secretion of vital force", are in my view a distortion of the Igbo idea of personal identity. I do accept these scholars' views as approximating the Igbo concept of reincarnation, and it must be said that the Igbo are not always able to fully express what they mean by this concept. Still, from the point of view of Igbo anthropology, the ideas shared above are not only a distortion of the Igbo idea of humanity and personal identity, but also untenable in the non-dualistic Igbo concept of reincarnation. ${ }^{2}$

Furthermore, the ritual for identifying the reincarnated dead person is called in many areas in Igboland "Igba-agu" ("divining for the reincarnate person”). Only the traditional Igbo diviners (dibia afa) can authoritatively pronounce the name of the reincarnated person through igba afa. Ekwealor (2013) described igba afa as a means of finding out the hidden things which are elusive to an ordinary person. It is the means of finding out the thoughts of the deities and the ancestors. For Ogbuagu, Udemmadu and Anedo (2012) igba afa means gaining access to secret things that we cannot find out on our own. According to Ubesie (2003), igba afa is a means of finding any secret that exists between the living and the dead or between two or more living persons. Umeodinka (2015) understands igba afa to be the means through which the Igbo people

\footnotetext{
'The translation of reincarnation in Igbo is ilo-uwa. However, Obilor and Ekwunife argued that the word, ilo-uwa, should be used rather than its English equivalent. Reincarnation could be described as the belief in the autonomy of the human soul, which passes out of a dead person into another body different from the original body whether this body is a human being, an animal, a vegetative or moral being. Ilo-uwa is the belief that the qualified deceased or living persons can return to earth through birth in their grandchildren, great grandchildren or the children of their relatives within the extended family.
}

${ }^{2}$ Reincarnation proposes dualism of body and soul. Igbo anthropology on the other abhors any form of dualism. The Igbo do not talk about soul, but person. Humans are spiritual persons. The living dead are spiritual persons but superior to humans. 
bring out the hidden things from the realm of darkness into the daylight of knowledge.

It is worth noting at this point that for Christians, the Scripture does not support this process of divination. In Deuteronomy 18:9-11, the verses contain a list of occult magic practices, common in the religions of Canaan, which were an abomination to God and forbidden by Him. Divination (igba-afa) is included in that list. Those among God's Old Testament people who practiced such things were put to death (Levi. 20:27). Likewise, the New Testament declares that those who practice such things will not enter the Kingdom of God (Gal. 5:20-21; Rev. 22:15).

Igbo people rely on experience to prove that reincarnation is real. Experience, they say, is the best teacher. They base reincarnation on what is visible or sensible or perceptible or the like. No one can tell someone that what he or she sees with their own eyes does not exist. Throughout the Igboland, people abound who are said to be the reincarnation of one deceased person or another. There are signs, marks, remembered talks and promises given when they were about to die that identify the previous reincarnation of the person in the currently living one. Of course, these claims must be backed up with the confirmatory affirmation of the dibia afa (diviner).

So when a child is born, during igu aha (the naming ceremony) the okpala (the family head) or the father of the child or both will consult the diviner to discover the ancestor who has been reincarnated, and especially to discover his or her name and nso (prohibitions). The child must take the name of the reincarnated ancestor, but when no reincarnation has been confirmed, the patriarchal grandfather or the eldest man present has the prerogative of giving the child a name. The divination rite which precedes the naming ceremony is to establish the identity. The naming ceremony is to effect the newborn's incorporation into the society.

\section{The Igbo Understanding of Humankind versus Scripture}

In Igbo anthropology, human beings (mmadu) are neither a dichotomy of body and soul nor a trichotomy of body, soul and spirit. Mmadu is a unity of personality. The spiritual anatomy of a person for the Igbo is ahu, (body), mkpuruobi (seed of the heart) and muo (spirit). ${ }^{3}$ According to Obilor (1994), the spirits on the other hand are made up of the spirit ancestors and the spirit deities which are invisible; the malignant spirits or attacking spirits which are visible only to the dibia (diviner) and in the form of mba muo (the attack by the evil spirit); and the spirit messenger (mmuo). Although the Igbo are very much at home with pneumatology, the concept of Holy Spirit is strange to them. The doctrine of the Holy Spirit falls outside their belief system because they have nothing to do with a Three in One God. Be this as it may, the Igbo share the concept of humankind with the Hebrews.

Abogunrin (1991) points out that in the Old Testament a person is not considered an immortal soul temporarily inhabiting a mortal body, but rather as a body-soul unity. The Hebrews could only conceive of personhood in its totality, as the vital union of body and soul. According to ancient Jewish belief, we are a product of two factors, namely nepeš (breath or soul, which is the principle of life) and basher (body or flesh which is the complex organ that nepeř animates). A person may therefore be described as an animated body, but this falls short of a true description since in this regard we are not different from the animal creation (Gen. 2:19). Genesis 2:7 says: "Then the LORD God formed man out of dust from the ground and breathed into his nostrils the breath of life and man became a living being”(NIV). Clark (1967) contends that human distinctiveness is based on the fact that to humanity alone is imparted the breath of life by the direct activity of God. Although the use of nepeř in Genesis 2:7 denotes a complete being, according to the general understanding of the Old Testament, neither basher nor nepeš alone can make a complete person. A human being is a unified person, and the dissolution of either the soul or the body means the true end of life. Nepešs closely connected with blood, so the loss of blood is the tangible mark of a passing away of life. Therefore nepeš is spoken of as being breathed out (Gen. 2:7; 35:18; 1 Kg. 17:22). The whole of a person's intense emotions and desires are attributed to his or her nepeř. That is, the term is invariably used for a living self, or as a substitute for a personal pronoun.

A person also has a $r \bar{u} a h$ (spirit) denoting the invasive power of God. From the time of the exile, there was a tendency to replace nepeš with $r \bar{u} a h$ as the centre of aspiration and desires. The absence of ruah is the loss of life and vitality, and ultimately death (1 Kg. 10:5; Ps. 104:29). The return of rūah means revival (Gen. 45:27). While nepeš refers to the life concretely manifested, $r \bar{u} a h$ means the hidden strength of a living person. So, for the Hebrews as well as for the Igbo, there is no division between the soul and the body.

${ }^{3}$ It has to be noted that although the Igbo people recognise three components of a person, yet they consider the whole person as a unit. The soul without the body is not considered as a person. For any human to attain the status of a person in Igbo anthropology, the three components must be present. This is the major difference between the Igbo notion of reincarnation and the Asiatic concept where an aspect of a person like a soul can inhabit another body for another earthly existence. 
What lives in the underworld is not just the soul but the whole person. Hence the dead are not called nepešnor ıйah, but rephaim. At death, a shadowy image of the person is detached from him or her. As long as the body exists, or at least the bones remain, the essential person still exists like a shade under the condition of extreme weakness (Job 26:5-6; Isa. 14:9-10; Ez. 32:1732 ). The soul continues to feel the care and honour bestowed on the body.

\section{Differences between Resurrection and Reincarnation}

Resurrection is considered to be a miracle whereas reincarnation in Igbo cosmology is the resultant effect of a natural process of rebirth.

Again, in resurrection, there is a bodily continuity whereas in reincarnation in Igbo cosmology the old body and the new body are considered in symbiotic association.

Furthermore, resurrection is a one-time event that is never repeated unlike reincarnation in Igbo worldview which is repeated.

Moreover, Christians will possess bodies that are not only new but will possess higher powers than the ones they had before in their earthly lives. Their bodies will not only be transformed but will also be glorious. Resurrected individuals are not the causal elements that bring about transformation. They are rather the passive elements. Their transformed and glorious bodies are the direct activity of God. These bodies are no longer subjugated to earthly limitations. Although they are changed when they die, yet they remain the same. The new bodies have material continuity with the old ones. The only difference now is that they seem to belong to a different order of reality. This is not so in the Igbo belief in reincarnation where the ancestors are the active agents in reincarnation and where the reincarnated individuals still undergo earthly limitations as in the days of the past.

Finally, the most distinctive proofs of ilo-uwa or reincarnation are based on visible or sensible resemblance; the reappearance of marks on the body, the 'relacking' of a lacking part of the body, the facial and physical resemblance, the vocal and oratorical resemblance and all other resemblances. This is anchored on resemblance theory. This is not so in the resurrection where it is one and the same person who died who is risen.

\section{Conclusion}

That which brought the Church into being and gave it a message was not the hope of the persistence of life beyond the grave, nor the confidence that the dead ancestors will return to their immediate families and relatives, nor the confidence in God's supremacy over death, nor the conviction of the immortality of the human spirit. Rather, it was the belief in an event in time and space: Jesus of Nazareth was raised from the dead and His resurrection is the basis of believers' resurrection. There are stories of restorations to life, but these are mere 'resuscitations of corpses'. Jesus' resurrection, and by implication, believer's resurrection is not the restoration to physical life of a dead body; it is the emergence of a new order of life. It is the embodiment in time and space of eternal life. It is the beginning of the eschatological resurrection. It therefore stands in sharp contrast to Igbo belief in reincarnation.

An Igbo Christian lives in two worlds-the world of culture (which is inseparable from the world of former religion) and the world of Christian religion (into which he or she is baptized),sometimes without real conversion and discipleship. When such people find themselves in moments of crisis-sickness, matrimony, the birth of a child, a funeral of relatives, the construction of a house and, for students, facing important and difficult examinations-it is not rare to find them having recourse to superstitious practises of the former religion. Proper inculturation occurs when a person is alive in his or her culture and Christian faith. This is because through inculturation the Church makes the Gospel incarnate in different cultures, and at the same time transmits to them its own values, taking the good elements that already exist and renewing them from within.

Christians see life as linear and sequential, proceeding towards ultimate consummation, but with a split ending in the afterlife. This is in contradistinction to Igbo cyclical notion of history as seen in their belief in reincarnation. This has significant theological implications for Christian ministry for the Church in Igboland.

The Church in Igboland needs a genuine Igbo expression of the Christian faith and a corresponding theology in order to communicate better with God and all of humanity. Here are my recommendations:

1. Given that God in Igbo religion is understood as Chukwu and not as Triune God, it is therefore recommended that the concept of Holy Trinity should form part of the Church's message in evangelistic enterprise.

2. The Church in its evangelistic outreach should present the resurrection of the dead as the work of the Triune God. It should teach that the resurrection is one of the events of the 'end of time' and history.

3. Sacrifice is the knife-edge on which Igbo religion rests. The fact that in Igbo religion sacrifices for the dead are intended to remove all obstacles for the dead, 
including those which may frustrate one's possible reincarnation, gives impetus for evangelization. The Church should therefore use Igbo sacrifices as an inculturated teaching towards a better understanding of Christ Jesus' once and for all sacrifice for sins on the cross.

4. Christ can be presented to the traditionalists as the Universal Ancestor. Just as He not only rose from the dead but is also seen as the Life and Resurrection, so He can be seen as the Ancestor. Consequently, the Church can begin dialogue here and launch into a better understanding of the true meaning and value of the Lordship of Christ.

5. Igbo religion has no room for the Holy Spirit given that it lacks the concept of the Three Persons in One God. Nevertheless, it has ample room for spirits and thus is attuned to pneumatology. This can serve as a possible element of inculturation. Proceeding from what the Igbo Christians know through the traditional religion about the spirits in general, the Church can produce for them a serious teaching which will give the Holy Spirit a right place in the Igbo system of belief.

6. Although Igbo religion sees people as unities both in life and death, it neither addresses the question of personal identity nor considers it to be important. At best, it points to resemblance theory. The Church can take Igbo anthropology from that standpoint and lead the Igbo Christians to a better perspective of personal identity after death when Christ raises us up at the last day.

7. Given that the Easter event gives meaning to the mystery of life and death, and that it can be misrepresented through bad customs and practices, the onus of responsibility lies on the Church to continue to teach and affirm the doctrine of resurrection of the dead.

8. Admission into the ancestral cult is by the judgments of the ancestors which are based on a spotless life, founding lineages, ripe old age, and proper burial. These conditions are not within the reach of everybody. However, this belief could serve as a bridge for Igbo Christians to a better understanding of last judgment of Christ.

9. An Igbo person should see people's positive qualities as the effects of genetic inheritance, not as signs of prior lives. A Christian understanding of resurrection brings the hope of glory in the future.

\section{References}

Abogunrin, S. O. 1991. Immortality and Resurrection in Early Judaism. Orita:Journal of Religious Studies XXXIII(1-2):15-34.

Anozia, I. P. 1968. The Religious Import of Igbo Names. Unpublished Thesis. Rome: Urban University.
Brown, R. E. 1974. The Virginal Conception and the Bodily Resurrection of Jesus. London: Geoffrey Chapman.

Bultmann, R. 1965. The Theology of the New Testament, Volumes 1 and 2. Translated by Kendrick Grobel. New York: Scribner's.

Clark, E. A. 1967. The Origenist Controversy. Princeton: Princeton University Press.

Cravig, C. T. 1953. Interpreter's Bible. Nashville: Abingdon.

Dahl, M. E. 1978. The Resurrection of the Body. Nashville: Abingdon.

Davies, W. D. 1962. Paul and Rabbinic Judaism: Some Rabbinic Elements in Pauline Theology. London: S. P. C. K.

Ekwealor, C. C. 2013. Agumagu Ederere Igbo N'Ozuzuoke. Nsukka: Paschal.

Hering, J. 1964. The First Epistle of Paul to the Corinthians. London: Epworth.

Isidienu, I. C. 2015. Echichendi Igbo Gbasara Chukwu, Ndichiena Onwu. In Omumu Agumaguna Omenala Igbo. Gladys I. Udechukwu et al., eds. Pp. 108-112. Fornat Publishers.

Jeremias, J. 1955-56. Flesh and Blood Cannot Inherit the Kingdom of God. New Testament Studies 2:151-159.

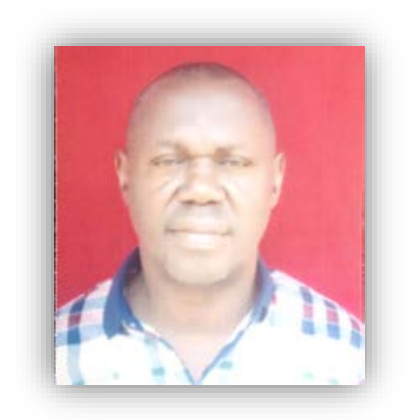

Valentine Chukwujekwu Mbachi (Ph.D), lectures in New Testament Studies in the Department of Religion and Human Relations, Faculty of Arts, Nnamdi Azikiwe University, Awka, Nigeria.

Author email: valmbachi@gmail.com vc.mbachi@unizik.edu.ng 